\title{
HUBUNGAN ANTARA KESEPIAN DENGAN SELFIE-LIKING PADA MAHASISWA
}

\author{
Evina Krisnawati, Christiana Hari Soetjiningsih \\ Fakultas Psikologi, Universitas Kristen Satya Wacana Salatiga \\ Jl. Diponegoro 52-60 Salatiga 50711 Jawa Tengah \\ evinakrisnawati@gmail.com
}

\begin{abstract}
This study aims to examine the relationship between loneliness and selfie-liking. The hypothesis of this research is that there is a positive relationship between loneliness and selfie-liking among college students. This research used correlational quantitative methods. Participants in this research was 64 students, which was taken by purposive sampling technique, with inclusive criteria: like to do selfie and in the last month post the selfie photos to social media as much as 4-6 times. Data were collected using the Loneliness Scale from UCLA Version 3 and selfie-liking measured by Selfie-Liking Scale. The correlation was analyzed using the Spearman Correlation Test with SPSS 23 for Windows. The results showed there was a positive and significant relationship between loneliness and self-liking $(r=.297 ; p=.009)$ which means the higher loneliness, the higher selfie-liking.
\end{abstract}

Keywords: loneliness; selfie-liking; college student

\begin{abstract}
Abstrak
Penelitian ini bertujuan untuk menguji hubungan antara kesepian dengan selfie-liking. Hipotesis penelitian ini adalah ada hubungan positif antara kesepian dengan selfie-liking pada mahasiswa. Penelitian ini menggunakan metode kuantitatif korelasional. Partisipan dalam penelitian ini adalah 64 mahasiswa yang didapatkan dengan teknik purposive sampling, dengan kriteria menyukai selfie dan dalam sebulan terakhir mengunggah foto selfie ke media sosial sebanyak 4-6 kali. Data dikumpulkan dengan menggunakan Skala Kesepian dari UCLA Version 3 dan selfie-liking diukur dengan Skala Selfie-Liking. Analisis data menggunakan korelasi Spearman dengan bantuan program SPSS 23 for Windows. Hasil menunjukkan ada hubungan positif dan signifikan antara kesepian dengan selfie-liking $(r=0,297 ; p=0,009)$. Hal tersebut menunjukkan semakin tinggi rasa kesepian maka semakin tinggi selfie-liking.
\end{abstract}

Kata kunci: kesepian; selfie-liking; mahasiswa

\section{PENDAHULUAN}

Fenomena selfie atau dikenal sebagai swafoto beberapa tahun terakhir menjadi tren. Menurut Charoensukmongkol (2016), selfie adalah foto potret diri yang diambil menggunakan kamera digital atau kamera telepon. Mengambil foto selfie telah menjadi kegiatan yang populer di mana individu melakukannya untuk menampilkan diri ke publik. Individu biasanya mengirimkan (posting) foto selfie ke situs jejaring sosial seperti facebook dan instagram, dan membagikannya pada teman-teman yang ada dalam jejaring sosial tersebut. Pada tahun 2014, diperkirakan ada lebih dari 17 juta foto selfie diunggah ke media sosial setiap minggunya dan ada lebih dari 24 miliar foto selfie tersimpan di server google pada tahun 2015 (Gray, 2016).

Individu yang menyukai selfie dalam sebulan dapat mengirimkan foto selfie ke media sosial rata-rata sebanyak 4-6 kali (Borelli, 2016). Hampir sepertiga dari semua foto selfie diambil oleh individu yang berusia antara 18-24 tahun dan sampai saat ini lebih dari 300 juta foto selfie telah dikirimkan di instagram. 
Diperkirakan bahwa generasi milenium rata-rata akan menghabiskan waktu sekitar satu jam seminggu untuk mengambil hingga 25.700 foto selfie dalam hidupnya (Samsung, 2016). Hasil survei awal berupa wawancara singkat yang dilakukan oleh peneliti kepada 30 mahasiswa di Fakultas Psikologi Universitas Kristen Satya Wacana Salatiga didapatkan hasil bahwa $70 \%$ mahasiswa suka berfoto selfie dan $67 \%$ sering mengirim foto selfie-nya yaitu 4-6 kali atau lebih ke situs jejaring sosial dalam sebulan terakhir.

Individu melakukan foto selfie dengan tujuan untuk menghibur diri atau untuk mengisi waktu luang dan ingin mendapat perhatian dari orang lain (Yulistara, 2014a). Menurut Houghton (dalam Widiani, 2013) seseorang yang secara berkala mengirimkan foto selfie-nya di media sosial berisiko membahayakan dirinya di kehidupan nyata. Hal ini dapat berpotensi memperburuk hubungan sosialnya atau membuat pengunggah foto kurang disukai orang lain dikarenakan tidak semua orang berhubungan baik dengan orang yang mem-posting foto selfie-nya. Menyebarkan foto selfie ke media sosial juga dapat berisiko mengundang kejahatan, membuat pekerjaan terbengkalai, menganggu orang lain, memengaruhi pikiran orang lain yang melihat, dan meningkatkan risiko picture exchange affair (Yulistara, 2014b).

Selfie-liking adalah sejauh mana individu merasa terhubung secara emosional untuk melakukan selfie dan mengintegrasikannya ke dalam kegiatan sehari-hari. Indikator selfie-liking adalah: a) menikmati kegitan mengambil foto selfie; b) merasa bahwa mengambil foto selfie merupakan kegiatan yang penting dalam kehidupan sehari-hari; c) selalu mencari tempat di mana dapat mengambil foto selfie (Charonsukmongkol, 2016).

Selfie-liking dipengaruhi oleh beberapa faktor yaitu narsisme, attention-seeking behavior, self-centered behavior, kesepian, usia, gender, intensitas penggunaan media sosial, friendliness, dan peer pressure (Charoensukmongkol, 2016). Sejauh penelusuran penulis pada beberapa jurnal, belum banyak penelitian tentang hubungan selfie liking dan faktor-faktor yang memengaruhinya, terutama berkaitan dengan kesepian. Ada satu penelitian yang telah dilakukan oleh Charoensukmongkol (2016) dengan judul "Exploring Personal Characteristics Associated with SelfieLiking" dengan sampel mahasiswa sarjana dan pascasarjana di Bangkok, Thailand, yang mengungkapkan hasil bahwa ada hubungan positif antara selfie-liking dengan kesepian.

Menurut Russell (dalam Lou, Yan, Nickerson, \& McMorris, 2012) kesepian didefinisikan sebagai hubungan sosial yang tidak sesuai dari apa yang diinginkan atau dicapai, termasuk perasaan gelisah, tertekan, dan persepsi kurangnya hubungan sosial pada diri seseorang. Adapun aspek kesepian menurut Russell (1980) yang digunakan sebagai dasar penyusunan UCLA Loneliness Scale adalah, a) Trait loneliness yaitu adanya pola yang lebih stabil dari perasaan kesepian yang terkadang berubah dalam situasi tertentu, atau individu yang mengalami kesepian karena disebabkan kepribadian mereka. Kepribadian yang dimaksud adalah seseorang yang memiliki kepercayaan yang kurang dan ketakutan akan orang asing, b) Social desirability loneliness yaitu terjadinya kesepian karena individu tidak mendapatkan kehidupan sosial yang diinginkan pada kehidupan di lingkungannya, c) Depression loneliness yaitu terjadinya kesepian karena terganggunya perasaan seseorang seperti perasaan sedih, murung, tidak bersemangat, merasa tidak berharga dan berpusat pada kegagalan yang dialami oleh individu.

Individu yang merasa kesepian dapat menurunkan derajat kesepiannya dengan 
cara melakukan kontak sosial (Peplau \& Perlman, dalam Serra, 2015). Kemajuan teknologi memungkinkan kontak sosial dilakukan dengan memanfaatkan situs jejaring sosial yang kini sangat mudah diakses melalui ponsel cerdas. Penelitian yang ada menunjukkan bahwa kesepian berhubungan kuat dengan intensitas kegiatan jejaring sosial, terutama dalam hal mengirim dan berbagi informasi (Lou dkk, 2012; Skues, William, \& Wise, 2012). Jumlah waktu yang dihabiskan secara teratur di situs jejaring sosial ditemukan sebagai faktor yang sangat menjelaskan intensitas individu dalam mengirimkan foto selfie (Fox \& Rooney, 2015; Lou dkk, 2012; Weiser, 2015). Dari temuan tersebut, dapat dilihat bahwa kesepian membuat individu lebih sering terlibat dalam kegiatan di jejaring sosial termasuk membagikan foto selfie (Lou dkk, 2012). Berkaitan dengan temuan tersebut, Charoensukmongkol (2016) melakukan penelitian analisis faktor selfie-liking dan memberikan bukti tambahan bahwa individu yang gemar mengambil foto selfie kemudian membagikannya di situs jejaring sosial ternyata memiliki tingkat kesepian yang lebih tinggi.

Dari penelusuran peneliti terhadap beberapa penelitian terdahulu selain yang dilakukan oleh Charonsukmongkol (2016), belum ada yang mengkaitkan selfie dengan kesepian, selfie lebih banyak dikaitkan dengan narsisme, diantaranya adalah penelitian yang dilakukan oleh Fox dan Rooney (2015) yang menemukan bahwa ada hubungan yang kuat antara narsisme dan jumlah foto selfie yang di-posting. Lalu Weiser (2015) yang menemukan bahwa frekuensi selfie-posting sangat terkait dengan dimensi narsisme yaitu leadership atau authority dan grandiose exhibitionism. Sorokowski, Sorokowska, Oleszkiewicz, Frackowiak, Huk, \& Pisanski (2015) juga meneliti tentang selfie dan menemukan adanya hubungan antara skor narsisme secara keseluruhan dengan selfie-posting lebih kuat untuk laki-laki dari pada untuk perempuan.

Sementara itu, penelitian terdahulu tentang hubungan antara kesepian dengan selfieliking yang dilakukan oleh Charonsukmongkol (2016) masih memerlukan penelitian lebih lanjut, karena pada penelitian tersebut hanya menggunakan aitem alat ukur yang sangat minim, di mana alat ukur yang digunakan mengukur banyak variabel lain selain kesepian dan selfie-liking sehingga pengukuran hubungan antara kesepian dan selfie-liking kurang spesifik. Oleh karena itu, berdasarkan uraian yang telah dipaparkan penulis ingin membuktikan adanya hubungan antara kesepian dengan selfie-liking pada mahasiswa.

Hipotesis dari penelitian ini adalah ada hubungan yang positif antara kesepian dengan selfie-liking pada mahasiswa. Makin tinggi rasa kesepian maka makin tinggi selfie-liking. Penelitian ini dilakukan dengan tujuan untuk mengetahui hubungan antara kesepian dengan selfie-liking pada mahasiswa.

\section{METODE}

Penelitian ini termasuk jenis penelitian kuantitatif dengan metode penelitian korelasional. Proses pengumpulan data dilakukan pada bulan Januari 2017. Subjek dalam penelitian ini adalah mahasiswa Fakultas Psikologi UKSW Salatiga yang berjumlah 64 orang (28 laki-laki dan 36 perempuan). Teknik sampling yang digunakan adalah purposive sampling dengan kriteria merupakan mahasiswa Fakultas Psikologi UKSW Salatiga yang menyukai selfie dan dalam sebulan terakhir mem-posting foto selfie ke media sosial sebanyak 4 - 6 kali.

Alat ukur yang digunakan untuk mengukur kesepian dalam penelitian ini adalah Skala Kesepian dari UCLA Version 3 yang dikembangkan oleh Russell (1996). Terdiri 
dari 20 aitem $(\alpha=0,865)$ yang telah penulis sesuaikan dan terjemahkan dalam Bahasa Indonesia. Selfie-liking diukur dengan menggunakan Skala Selfie-liking $(\alpha=0,909)$ yang disusun oleh peneliti yang terdiri dari 32 aitem berdasarkan indikator selfie-liking dari Charoensukmongkol (2016), yaitu menikmati kegitan mengambil selfie, merasa bahwa mengambil foto selfie merupakan kegiatan yang penting dalam kehidupan sehari-hari, selalu mencari tempat di mana dapat mengambil foto selfie, dan marah jika dicegah dari kegiatan mengambil foto selfie. Menurut Kaplan \& Saccuzzo (2013) standar reliabilitas yang baik adalah 0,8. Maka dapat dikatakan bahwa Skala Kesepian dan Skala Selfieliking ini memiliki reliabilitas yang baik.

Untuk melihat hubungan antara kesepian dengan selfie-liking pada mahasiswa dilakukan uji korelasi Spearman dengan bantuan program SPSS.

\section{HASIL DAN PEMBAHASAN}

Dari hasil analisis deskriptif diperoleh skor kesepian minimum 34 dan maksimum 58 $(\mathrm{M}=45,28, \mathrm{SD}=7,063)$. Skor selfie-liking, minimum 58 dan maksimum 102 ( $\mathrm{M}=$ $85,62, \mathrm{SD}=10,648)$.

Dari hasil kategorisasi diperoleh data bahwa terdapat 6 mahasiswa $(9,38 \%)$ yang kesepiannya ada pada kategori tinggi, 29 mahasiswa $(45,31 \%)$ ada pada kategori cukup dan 29 mahasiswa $(45,31 \%)$ ada pada kategori rendah. Pada variabel selfie liking terdapat 25 mahasiswa $(39,06 \%)$ ada pada kategori tinggi, 35 mahasiswa $(54,69 \%)$ ada pada kategori cukup dan 4 mahasiswa $(6,26 \%)$ ada pada kategori rendah.

Berdasarkan uji korelasi yang dilakukan menggunakan Spearman Correlation Test, diperoleh nilai $r=0,297 ; \quad p=0,009$. Berdasarkan hasil tersebut dapat disimpulkan bahwa hipotesis yang berbunyi ada hubungan positif antara kesepian dengan selfie-liking pada mahasiswa dapat diterima. Arah korelasi yang positif menunjukkan bahwa semakin tinggi tingkat kesepian, maka semakin tinggi pula tingkat selfie-liking. Sebaliknya, semakin rendah tingkat kesepian, maka semakin rendah pula tingkat selfie-liking-nya.

Hasil analisis deskriptif menunjukkan bahwa sebagaian besar $(45,31 \%)$ mahasiswa tingkat kesepiannya ada pada kategori cukup dan dan sebagian besar lainnya $(45,31 \%)$ pada kategori rendah. Sedangkan untuk tingkat selfie-liking-nya sebagian besar $(54,69 \%)$ ada pada kategori cukup.

Dari hasil penelitian ini dapat diketahui bahwa ada kesesuaian dengan penelitian terdahulu yang dilakukan oleh Charoensukmongkol (2016) yang menemukan bahwa individu yang gemar mengambil foto selfie kemudian membagikannya di situs jejaring sosial ternyata memiliki tingkat kesepian yang lebih tinggi. Mengambil foto selfie, memungkinkan individu untuk mendapatkan kontrol penuh dari apa yang orang lain lihat dalam fotonya, mereka yang menyukai selfie tidak jarang menghabiskan waktu untuk mengedit foto selfie-nya dan kemudian mem-postingkannya ke media sosial dengan harapan bahwa orang lain yang melihat foto selfienya menjadi terkesan dan kemudian mau memberi umpan balik. Umpan balik yang didapat ini memungkinkan individu untuk merasa secara sosial terhubung dengan orang lain (Weiser, 2015).

Individu yang kesepian cenderung ingin melakukan kontak sosial agar terhubung dengan orang lain guna mengurangi rasa kesepiannya (Peplau \& Perlman, dalam Serra, 2015). Interaksi sosial yang dimaksudkan dalam penelitian ini adalah melalui situs jejaring sosial, yaitu melalui komentar atau umpan balik yang didapat 
pada foto selfie yang telah di-posting-kan karena orang lain terkesan dengan foto selfie tersebut. Dari uraian tersebut dapat dijelaskan bahwa individu dengan tingkat kesepian yang lebih tinggi cenderung melaporkan selfie-liking di tingkat yang lebih tinggi dibandingkan dengan orang dengan tingkat kesepian yang lebih rendah.

Dari hasil perhitungan lebih lanjut, didapatkan bahwa $\mathrm{r}^{2}=0,088$ yang berarti variabel kesepian memberikan sumbangan sebesar $8,8 \%$. Hal ini juga menunjukkan bahwa $91,2 \%$ tingkat selfie-liking dipengaruhi oleh faktor lain. Adanya faktor lain yang berpengaruh terhadap selfieliking ini dibuktikan dengan adanya penelitian terdahulu, seperti penelitian dari Fox dan Rooney (2015) yang menemukan bahwa ada hubungan yang kuat antara narsisme dan jumlah foto selfie yang diposting. Lalu Weiser (2015), yang menemukan bahwa frekuensi selfie-posting sangat terkait dengan dimensi narsisme yaitu leadership atau authority dan grandiose exhibitionism. Sorokowski dkk (2015) menemukan adanya hubungan antara skor narsisme secara keseluruhan dengan selfie-posting lebih kuat untuk lakilaki dari pada untuk perempuan. Charoensukmongkol (2016) juga mengungkapkan hasil bahwa selfie-liking dipengaruhi oleh banyak faktor lain selain kesepian, seperti narsisme, attentionseeking behavior, self-centered behavior, usia, gender, intensitas penggunaan media sosial, friendliness, dan peer pressure.

Dari hasil penelitian ini, dapat diberikan saran bagi beberapa pihak. Bagi mahasiswa dan pelaku selfie, dalam penelitian ini ditemukan bahwa kesepian memiliki korelasi yang positif dan signifikan dengan selfie-liking. Maka disarankan bagi mahasiswa dan pelaku selfie untuk melakukan evaluasi diri terhadap perilaku selfie yang dilakukan terutama apabila perilaku selfie sampai merugikan diri sendiri atau orang lain. Apabila perilaku selfie yang dilakukan disebabkan karena kesepian, sebaiknya mahasiswa maupun pelaku selfie dapat mencegah diri dari perilaku selfie yang berisiko dan merugikan orang lain, serta melakukan upaya lain untuk meminimalisir rasa kesepiannya dengan kegiatan lain yang lebih bermanfaat. Bagi peneliti selanjutnya, disarankan untuk melakukan pengembangan maupun modifikasi terhadap penelitian ini baik dengan pokok bahasan yang sama namun dengan menambah sampel atau menggunakan sampel yang berbeda maupun dengan memperluas dari segi metode, teori, maupun alat ukur yang digunakan.

\section{SIMPULAN}

Berdasarkan hasil penelitian yang telah dilakukan, hasil uji korelasi menunjukkan adanya hubungan positif dan signifikan antara kesepian dengan selfie-liking pada mahasiswa $(r=0,297 ; p=0,009)$.

\section{DAFTAR PUSTAKA}

Borelli, L. (2016, November). Selfie addiction: People who post selfpotraits on social media are extroverted, social exhibitionists. Medical Daily. Diakses dari: http://www.medicaldaily.com/selfieaddiction-people-who-post-selfpotraits-social-media-are-extrovertedsocial-361504 pada tanggal 30 Oktober 2016.

Charoensukmongkol, P. (2016). Exploring personal characteristics associated with selfie-liking. Cyberpsychology: Journal of Psychosocial Research on Cyberspace, 10(2), article 7. doi: 10.5817/cp2016-2-7.

Fox, J., \& Rooney, M. C. (2015). The dark triad and trait self-objectification as predictors of men's use and selfpresentation behaviors on social networking sites. Personality and Individual Differences, 76, 161-165. doi: 10.1016/j.paid. 2014.12.017. 
Gray, R. (2016, Juni). What a vain bunch we really are! 24 billion selfies were uploaded to google last year. Daily Mail. Diakses dari: http://www. dailymail.co.uk/sciencetech/article-36 19679/What-vain-bunchreally24-billi on-selfies-uploaded-Google-year.html pada tanggal 8 Oktober 2016.

Kaplan, R. M., \& Saccuzzo, D. P. (2013). Psychologycal testing - principles, application, and issues. (8th ed.). Belmon: Wadsworth Cengage.

Lou, L. L., Yan, Z., Nickerson, A., \& McMorris, R. (2012). An examination of the reciprocal relationship of loneliness and facebook use among first-year college students. Journal of Educational Computing Research, 46(1), 105-117.

Russell, D., Peplau, L.A., \& Cutrona, C.E. (1980). The revised UCLA Loneliness Scale: Concurrent and discriminant validity evidence. Journal of Personality and Social Psychology, 39, 472-480.

Russell, D.W. (1996). UCLA Loneliness Scale (Version 3): Reliability, Validity, and Factor Structure. Journal of Personality Assessment, 66, 20-44.

Samsung. (2016, April). Samsung selfie campaign wins african excellence award. Samsung. Diakses dari: http://www.samsung.com/za/news/loc al/samsung-selfie-campaign-winsafrican-excellence-award pada tanggal 10 Oktober 2016.

Serra, M. M. O. (2015). Spiritualitas pada remaja panti asuhan yang mengalami kesepian. Skripsi. Salatiga: Fakultas Psikologi Universitas Kristen Satya Wacana.

Skues, J. L., Williams, B., \& Wise, L. (2012). The effects of personality traits, self-esteem, loneliness, and narcissism on Facebook use among university students. Computers in Human Behavior, 28, 2414-2419. doi: 10.1016/ j.chb.2012.07.012.

Sorokowski, P., Sorokowska, A., Oleszkiewicz, A., Frackowiak, T., Huk, A., \& Pisanski, K. (2015). Selfie posting behaviors are associated with narcissism among men. Personality and Individual Differences, 85, 123127. doi: 10.1016/j.paid.2015.05.004.

Weiser, E. B. (2015). Me: Narcissism and its facets as predictors of selfieposting frequency. Personality and Individual Differences, 86, 477-481. doi: 10.1016/j.paid.2015.07.007.

Widiani, R. (2013, Desember). Efek positif dan negatif terlalu sering narsis di media sosial. Tribun Kesehatan. Diakses dari: http://www.tribunnews. com/kesehatan/2013/12/18/efek-posi tif-dan-negatif-terlalu-sering-narsis-dimedia-sosial pada tanggal 21 Mei 2017.

Yulistara, A. (2014a, Februari). Pamer foto selfie di media sosial, adakah manfaatnya? ini kata psikolog. Wolipop. Diakses dari: http://woli pop.detik.com/read/2014/02/07/11283 2/2490100 /852/pamer-foto-selfie-dimedia-sosial-adakah-manfaatnya-inikata-psikolog pada tanggal 8 Oktober 2016.

Yulistara, A. (2014b, Februari). Hati-hati! 5 dampak buruk yang bisa terjadi karena pamer foto selfie. Wolipop. Diakses dari: http://wolipop.detik. com/read/2014/02/07/130826/2490218 /852/hati-hati-5-dampak-buruk-yangbisa-terjadi-karena-pamer-foto-selfie pada tanggal 21 Mei 2017. 